\title{
ISLAMIC EDUCATION MODEL IN SENIOR HIGH SCHOOL
}

Ahmad Mohdlori, email: ahmadmuhdlori68@gmail.com

Postgraduate Doctoral Islamic Education Study Program

Wahid Hasyim University Semarang, Indonesia

\begin{abstract}
This study aims to examine and examine various models of Islamic education carried out in senior high schools. Islamic education is a field of study that must be carried out starting from elementary school to senior high school and even college, with the hope that students have understanding, experience and can practice religious teachings in accordance with Islamic concepts correctly and kaffah based on the Qur'an. an and Hadith. The model in Islamic education can be in the form of Islamic boarding system education, Integrated Islamic education, Islamic boarding school education, Kuttab education, religious education based on life skills. In the development of this model of Islamic religious education, it must be oriented to the philosophy of life in the form of philosophical, etymological and pedagogical. This research is categorized as library research using descriptive qualitative analysis of literature. The data collection technique uses a study of book texts on education and laws and government regulations that contain Islamic education, especially in senior high schools. The analysis used in this research is text content analysis.
\end{abstract}

Keywords: Islamic Education, Model and Senior High School

\section{Introduction}

Islamic education is a very important part of education related to aspects of attitudes and values, namely morals and religion. Islamic education is a shared responsibility between family, community and government. To achieve the goals of Islamic education, the following educational elements are needed: 1. materials that are adapted to the level of mental development of students, 2. teachers who have the competence and requirements according to their fields, 3. facilities and infrastructure that are able to assist the implementation of education, 4. environment which supports the achievement of the expected goals in the form of a school situation, community and legislation. ${ }^{1}$

In the GBHN (MPR Decree Nomor IV/MPR/1978), regarding education, it is stated that education lasts a lifetime and is carried out within the household, school and community. It is also stated in the Law of the Republic of Indonesia number 20 of 2003 concerning the National Education System, chapter IV concerning the rights and obligations of citizens, parents, society and the government. ${ }^{2}$

Islamic Education is a subject as a field of study that must be taught in schools including high schools with the aim of achieving harmony and balance of one's personal growth as a whole with various trainings that include psychological,

${ }^{1}$ Zakiah Daradjat, et al, Ilmu Pendidikan Islam, (Jakarta : Bumi Aksara, 2011), 85

${ }^{2}$ RI Law No. 20 of 2003 concerning National Education System Chapter IV (Jakarta: Director General of Islamic Education, Ministry of Religion, 2007), 9-11 
intellectual, reason, feelings and senses. ${ }^{3}$ It is also stated in the National Education System Law number 20 of 2003 article 37 paragraphs 1 and 2, that Islamic Religious Education is a subject or field of study that must be taught in every curriculum, type, path and level of education. So Islamic Education has become a decision that has been regulated and guaranteed by the Indonesian government in this case the Ministry of Education to be applied, regulated and the implementation model in primary and secondary schools which are part of the overall national education system in Indonesia.

Judging from the law on the National education system, it is clear that Islamic Education is a national provision, guaranteed and regulated by the government for materials, implementation, models and evaluations. However, the reality is that there are still many problems that arise, especially the technique and model of providing education and teaching and learning process activities, the position of Islamic Education is a field of study in which several cases, its role also does not include components that determine the achievement index for students. There are also many problems that arise in Islamic Education, namely the lack of a number of lesson hours provided (ie 2-3 hours) with a lot of material that must be completed, educational methodologies that are not appropriate, the dichotomy of education carried out in schools which is sometimes considered inadequate. important, heterogeneity of knowledge and appreciation of the religion of students, attention and care by educational institutions in this case policy makers, namely leaders and even other teachers in schools. ${ }^{4}$

This study uses descriptive qualitative methods, namely research that starts from the reality in the world of secondary education with the assumption that human behavior in education has meaning for the perpetrators and the author tries to describe the data as they are by analyzing what is in accordance with the findings in the literature using an Islamic education approach.

Based on the preliminary description above, the authors formulate the problem as follows: 1. What is the model of Islamic education in senior high school ? 2. How

${ }^{3}$ M. Chabib Thoha, et al, Reformulasi Filsafat Pendidikan Islam, (Yogjakarta : Pustaka Pelajar, 1996), 299

${ }^{4}$ M. Chabib Thoha and Abdul Mu'ti, PBM PAI di Sekolah (Eksistensi dan Proses Belajar Mengajar Pendidikan Agama Islam, (Yogjakarta : Pustaka Pelajar, 1998), 5 
is the implementation of the Islamic education model in senior high school ? 3. What are the implications of the current Islamic education model in senior high school ? 4 . How is the development of Islamic education model in senior high school ?

To answer the formulation of this problem, it is necessary to discuss and describe several theories of Islamic education as follows.

\section{Discussion}

\section{Islamic Education and its Challenges.}

A model can be interpreted as a pattern (example, reference, variety and so on) of something to be made or produced. ${ }^{5}$ Or a simple picture meaning model that can explain an object, system or a concept of an object that will be created or produced. ${ }^{6}$ The model is a theoretical description of a process of Islamic education as a whole or is a description of one part of Islamic education.

Stephen P Robbins (1996) describes "A model is an abstraction of reality, a simplified representation of some real word phenomenon". Meaning: the model is a process of meaning from the phenomena that exist in the real world. ${ }^{7}$ Miarso (2008) also revealed that the model is the meaning of a process in graphic or narrative form, by showing several important elements and their structure. Then the narrative model can be interpreted into graphic form or vice versa. ${ }^{8}$ Models can help conceptualize the meaning of reality, simplifying the reality of something because real conditions are too complex to be seen.

In Law number 20 of 2003 concerning the National Education System chapter $\mathrm{X}$ article 37 paragraphs 1 and 2, it is stated that Islamic Education is a subject that must be included in the curriculum, type, path and level of education. In the decision that is mandatory in our country that the subject of Islamic Education in primary to secondary public schools and even universities is a comprehensive part of the

\footnotetext{
${ }^{6}$ M Zul Fajri, Kamus Lengkap Bahasa Indonesia, (Jakarta:Difa Publisher,2008), 572.

7 Stephen P Robbins, Organizational Behavior: Concepts, Controversies, Applications, (Prentice-Hall International, Inc, 1996), 25

${ }^{8}$ Yusufhadi Miarso, Penerapan Teknologi Informasi dan Komunikasi dalam Pendidikan di Era Globalisasi. Jakarta: Makalah Seminar Nasional The Power of ICT in Education, PPs UNJ, 15 April 2008, 12
}

${ }^{5}$ https://teropong.id/forum/2019/12/18/arti-kata-model-dalam-kamus-besar-bahasa-indonesiakbbi-adalah/ 1 
National Education System in Indonesia. This is firm and clear that the existence of Islamic Education in Senior High Schools is certainly very strong and becomes a mandate in the law that must be carried out in each of these schools.

The understanding of Islam in senior high school where Islamic Education learning from elementary school to senior high school is not enough to provide a strong religious education in order to live a happy world and prepare for the hereafter, so it is necessary to provide Islamic education in the form of teaching Islamic religious material. The reality that appears in the community of senior high school graduates is that there are still many outputs that have not been able to read, write let alone interpret or understand the content contained in the Qur'an, even very minimal practice according to the true contents of Islamic teachings. The reality in the community of many students is that there are brawls or fights, consuming narcotics and illegal drugs, promiscuity and so on which result in a moral crisis among students or the younger generation. Is this a lack of face-to-face Islamic education which is too little, in terms of religious material being so extensive and plentiful, or is this a failure of religious education that is taught in schools, especially moral education for students as the younger generation which is the shared responsibility as a community.

Thus, Islamic Education has several challenges faced at present and in the future. Abudin Nata (2013) conveyed several future challenges faced, namely:

First, there are trends in social, political, economic and scientific life that have emerged in the era of globalization, including:

a. the emergence of economic integration and free trade which makes education a traded commodity.

b. the emergence of demands for democratization and human rights that tend to be liberal and free which demands community-based education management and services, transparency, and student-centered learning models.

c. use of advanced technology in the form of IT (Information Technology) which requires the implementation and management of IT-based education such as learning, information and others. 
d. a permissive, dedonistic, materialistic and scularistic lifestyle which is reflected in patterns of thought, speech and action which in turn shifts the involvement of religious values. ${ }^{9}$

To face this global challenge, of course, the educational paradigm has changed its education and teaching by sticking to the values of Islamic teachings. Islamic Education must always improve and develop its excellence in various aspects, by innovating its Islamic teaching education programs so that they are interesting and interested and understood and even practiced by their educator participants.

Second, there is a tendency to change the lifestyle of an agrarian society into an urbanist lifestyle, namely a life that is lived in a hurry, life is considered a competitive thing, pragmatic attitudes and actions in overcoming problems, living with high mobility, and living lived with anonymous interactions or relationships (do not know each other with others). People who live in urban culture every day have to make decisions, experience new circumstances and meet new people more than what the villagers experience.

Third, there is a tendency to strengthen the understanding of progressive and pragmatic education. As the opinion of William James and John Dewey, the measure of progress is if the education held is able to encourage cultural change in society. Education must follow the dynamics of community development which tends to measure something useful in terms of mere material. Education not only provides theoretical knowledge in the classroom, but also provides real practical experience that is integrated by developing learning by doing, problem solving and problem based learning.

Fourth, there is a tendency for people to become increasingly intelligent and critical as a result of the development and progress of science and technology as well as various study methods and approaches, requiring an understanding and study of Islam that does not only use normative, perennialist and historical approaches, but with various approaches to scientific disciplines. - other sciences such as sociology, anthropology, psychology, and others. Without using these various approaches, Islamic religious studies will not be of interest to students/community, and even tend

${ }^{9}$ Abudin Nata, Kapita Selekta Pendidikan Islam : Isu-isu Kontemporer tentang Pendidikan Islam, (Jakarta : Raja Grafindo Persada, 2013), 89. 
to be abandoned which of course loses its relevance to the needs of students/community.

Fifth, there is increasing attention to Islamic Education by the Indonesian government for the progress of the nation in a balanced manner between physical and spiritual, intellectual and spiritual, material and spiritual. This can be seen in the various educational regulations and laws that regulate as a broad place in developing Islamic Education, as well as a lot of support in the form of infrastructure and funding for Islamic Education ranging from Elementary School, Junior High School to Senior High School even to university to become a model of education.

Ibn Hadjar (1999) said that Islamic Education is one of the subjects of study which together with other subject subjects, to form a complete human being. ${ }^{10}$ Thus, it can be understood that the occurrence of criminalization among the younger generation, especially among students, is a form of failure of education in schools, especially religious education. This is an attitude that needs serious attention, because the burden of fostering faith and piety is only on religious education. Islamic Religious Education is an integrated sub-system in national education which is of course oriented to the curriculum that has been set, which must work together and are interrelated.

\section{The History of Islamic Education}

In the early days of the growth of Islam, education was carried out by the Prophet Muhammad and focused on education of the Qur'an, namely reading the Qur'an and understanding its meaning. ${ }^{11}$ Prophet Muhammad conveyed the message to his family and close friends with direct revelation from Allah in the form of revelations of Islamic teachings.

At the beginning of its development, Islamic religious education can be seen more from the functional side, namely the process of holding education than from the perspective of the institutional form. The process of organizing Islamic education functions more as a place of education, besides being a place for Muslims to gather to

10 Ibnu Hadjar, Pendekatan Keberagamaan dalam Pemilihan Metode Pengajaran Pendidikan Agama Islam, (Yogyakarta : Pustaka Pelajar, 1999), 4.

${ }^{11}$ Djamaluddin Darwis, Dinamika Pendidikan Islam Sejarah, Ragam dan Kelembagaan, (Semarang : Rasail, 2010), 89. 
worship, it can also provide a more religious atmosphere, an atmosphere that is indispensable in Islamic education. ${ }^{12}$

Before the arrival of Europeans including the Dutch, Islamic education already existed and began to develop throughout the country. However, the implementation is still very simple (traditional) when compared to the development after the arrival of the Dutch. Islamic education runs and develops along with the da'wah and the spread of Islam itself, both in the community and in the courts of kings. Islamic education at that time took the form of halaqah and individual face-toface meetings in prayer rooms, mosques and Islamic boarding schools.

When the Dutch colonialists came, Islamic education began to experience obstacles. Obstacles and challenges to develop further along with the development and progress of that era occurred especially when faced with competition against Christianity which was actually carried out by the colonizers from the Portuguese to the Dutch. The Netherlands made various regulations and policies which essentially hindered and hindered the development and progress of Islamic education. ${ }^{13}$

When Japan colonized Indonesia with violence, they still provided opportunities for education, especially for Muslims. Even religious leaders are given leeway to develop education. Japan did not care about religious interests, because their interests were to colonize to win the war in the form of their power. Formal and non-formal educational institutions played a role in the struggle for Indonesian independence. With the struggle carried out by the Indonesian people, on August 17, 1945, the proclamation of Indonesian independence was carried out. On January 3, 1946, the Ministry of Religion was formed to deal with all religious fields. With the formation of the field that deals with religion, of course, it tries to develop its affairs, including the field of religious education. ${ }^{14}$

After Indonesia's independence, the government paid enough attention to Islamic education, namely on December 27, 1945 the Working Body of the Central National Committee held a discussion on religious education which contained: a) religious lessons in all schools, given during school hours, b) teachers are paid by the

${ }^{12}$ Ibid., 5

${ }^{13}$ Abudin Nata, Kapita Selekta Pendidikan Islam, (Bandung : Angkasa, 2003), 14.

${ }^{14}$ Ibid., 29. 
government, c) in elementary schools religious education is given starting in grade 6 given once a week, d) teachers are appointed by the department of religion, e) religious teachers are required to also be proficient in general education, $f$ ) the government provides books for religious education, g) training is held for religious teachers, h) the quality of pesantren and madrasas must be improved, i) teaching Arabic is not required. ${ }^{15}$

With further developments, the government drafted a law on the national education system to accommodate the contents of the 1945 Constitution concerning the education system carried out in Indonesia, which was subsequently ratified by Law No. 02 of 1989 on March 6, 1989. With this law, of course, further strengthening the implementation of Islamic education in schools even though the implementation is structurally discriminatory, such as religious education institutions or madrasas under the management of the Ministry of Religion, while general education is under the Ministry of National Education. However, the existence of this law Islamic education has the opportunity and opportunity to always develop its implementation in schools, senior high school which is very free and even very much needed by the community.

\section{Implementation of Islamic Education}

Islamic Education is one of the fields of study that must be taught in public schools, including Senior High School. Government Regulation of the Republic of Indonesia number 55 of 2007 concerning Religious Education in Chapter II article 3 paragraph (1) reads: every education unit at all lines, levels and types of education is obliged to provide religious education. And article 4 paragraph (1) says: religious education in formal education and equality education programs are at least held in the form of religious subjects or courses. ${ }^{16}$ And also in chapter $\mathrm{X}$ article 37 paragraph (1) says that the primary and secondary education curriculum must contain religious education. So Islamic Education is one of the mandatory fields of study that must be carried out in every type and level of national education, both public and private. In the GBPP Islamic Education in 1994 said that the purpose of Islamic Education in Senior High School is to increase the faith, understanding, appreciation and practice

${ }^{15}$ Ibid., 33. chapter IV

${ }^{16}$ Republic of Indonesia Constitution No. 20 year 2003 about the national education system 
of students about Islam so that later they become human beings who have noble character in personal life, in society. , nation and state. ${ }^{17}$

The scope of material for Islamic Education in Senior High School includes efforts to create harmony, harmony and balance in the relationship:

a. Man with God

b. Humans with each other

c. Man with himself

d. Humans with other creatures and the natural environment. ${ }^{18}$

The teaching materials for Islamic Education consist of seven points consisting of a) faith, b) worship, c) the Qur'an, d) morals, e) sharia, f) muamalah, and g) dates. ${ }^{19}$ This material certainly has implications for graduates who must be able to develop and realize elements in three educational domains, namely the cognitive, affective and psychomotor domains, with the hope that students can apply the values contained in these materials into everyday life at school and society, including the family environment.

There are several approaches taken in the Islamic Education curriculum in senior high school, including the following approaches:

a. Experience, namely an approach by providing religious experience to students in the context of inculcating religious values.

b. Habituation, namely the approach taken by providing opportunities for students to get used to carrying out religious teachings individually or in groups in daily behavior. The application of teaching methods in the form of drills, assignments, demonstrations and can be direct experience

c. Emotional, namely the approach taken with an effort to arouse the feelings or emotions of students in believing, understanding and living the teachings of Islam. The application of methods in the form of lectures, storytelling and sociodrama.

d. Rational, namely the approach by trying to give a role to the mind to understand and accept the truth of Islamic teachings by trying to understand the wisdom and

${ }^{17}$ Depdikbud RI, Kurikulum SMU-GBPP PAI, (Jakarta : Depdikbud RI, 1995), 1.

${ }^{18}$ Depag RI, Petunjuk Pelaksanaan Kuriklulum/GBPP Pendidikan Agama Islam Sekolah Menengah Umum, (Jakarta : Dirjen Pembinaan Kelembagaan Agama Islam, 1994), 3.

${ }^{19}$ Ibid. 
function of Islamic teachings. The application of the method includes lectures, questions and answers, discussions, group work, exercises and assignments.

e. Functional, namely an approach that seeks to present the teachings of Islam by prioritizing the emphasis on the benefits for students in daily life according to the level of development of these students. The application of the method includes exercises, assignments, lectures, questions and answers and demonstrations. ${ }^{20}$

\section{Model and Implementation of Islamic Education}

The Islamic Education model in educational institutions, including senior high school, has various models. This is influenced by several factors, including educational goals, managers/educators, students, environment, and other factors.

There are 5 models of Islamic Education, namely:

\section{a. Islamic Boarding System Education Model}

This education model is a strategic step by promoting an alternative pattern of Islamic education based on two functional ways, namely:

First, establishing an educational institution with Islamic-based components, namely: 1) a paradigmatic curriculum, 2) trustworthy and devoted teachers, 3) an Islamic teaching and learning process, and 4) an optimal school environment and culture. With efforts to minimize existing negative influences and increase positive influences on students, it is hoped that the influence given to students is in line with Islamic teachings.

Second, holding interactions between families and communities in order to have an optimal role so that they can support the process of Islamic religious education. The positive synergy of educational factors, namely schools, families and communities that make students have religious education in accordance with Islamic teachings. ${ }^{21}$ This model is mostly carried out in schools that have dormitories as a place to quarantine their students to stay in one place so that supervision and guidance is easier and there is not much negative environmental influence.

b. Integrated Islamic Education Model

${ }^{20}$ Ibid., 14

21 http://kamiluszaman.blogspot.com/2015/09/model-pendidikan-islam-dan-orientasinya. html, 10 
The curriculum content used in this Integrated Islamic school is a national curriculum colored with Islamic values through the addition of Islamic subjects, both separately and integrated. Curriculum design is oriented to the needs of students, the environment, and the development of today's science and technology. Curriculum implementation prioritizes functional and creative integration between cognitive, affective, and psychomotor aspects.

c. Islamic Boarding School Education Model.

This educational model is carried out by several schools whose educational environment is Islamic boarding schools or students living in Islamic boarding schools/dorms by using religious learning methods such as sorogan, wetonan/bandongan, halaqah, hiwar, bahsul masa'il, fathul polar and muqaranah. ${ }^{22}$ Curriculum design is oriented towards religious material in the books of fiqh, aqidah, Arabic grammar (nahwu sharaf), interpretation, hadith and others by implementing an understanding of religious material contained in the book or field of content being studied.

d. Kuttab Education Model (private)

In history, the model of Islamic education with Kuttab or private has existed since pre-Islam in the Middle East (Arabic). An educator provides a place in his house or other place such as a mosque or a designated room and receives a salary when an educator has carried out his learning. This model of religious education in the early days of Islamic history, there were two forms of kuttab, namely: 1) Kuttab functions as a place of education that concentrates on reading and writing. At this time, the Qur'an has not been used for reference as a subject with the aim of maintaining the purity of the Qur'an and does not seem to be played by students by writing and erasing it, in addition, followers of the Prophet Muhammad who can read and write the Qur'an still very little. 2) Kuttab serves as a place of religious education that teaches the Qur'an and the basics of religion. In this early era, the implementation of education was more focused on faith and character education and not yet on reading and writing the Qur'an. The implementation of this educational model is halaqah, but some use the method with the teacher reading a book aloud or using a loudspeaker, followed by the students.

${ }^{22}$ Ibid., 11. 
This process is carried out repeatedly until students really master the material being taught. ${ }^{23}$

e. Life Skills-Based Religious Life Education Model

This model is an educational model that internalizes the values of life skills in the family, school and community environment. Prof. Mudakkir Ali (2012), said the synergy of these values is very difficult to realize if it is not in one environment. In the family environment it is possible to grow aspects of selfawareness, but it is difficult to grow aspects of thinking skills, as well as in the community it is possible to be able to grow aspects of cooperation, but there are difficulties in growing awareness in students, and so on. So this educational model can realize the synergy of life skills values effectively if in one environment, because in it there is a systemic relationship in a system of cultural, social, structural and religious values so that between individuals there is a mutual learning society. $^{24}$

\section{Development Models of Islamic Education}

Government Regulation of the Republic of Indonesia number 55 of 2007 concerning Religious Education in chapter II article 5 states that:

a. The religious education curriculum is implemented according to the National Education Standards.

b. Religious education is taught according to the stage of psychological development of students.

c. Religious education encourages students to obey the teachings of their religion in daily life and make religion the basis of ethics and morals in personal, family, community, national and state life.

d. Religious education creates harmony, harmony, and respect among fellow believers of the religion adopted and towards adherents of other religions.

e. Religious education builds the mental attitude of students to behave and behave honestly, trustworthy, disciplined, hard working, independent, confident, competitive, cooperative, sincere and responsible.

${ }^{23}$ Ibid., 12.

${ }^{24}$ Mudzakkir Ali, Membangun Model Pendidikan Kehidupan Beragama Berbasis Life Skills di Pesantren, , Journal Edukasi, Vol. 10, Nomor 3 September-Desember 2012, 293. 
f. Religious education fosters a critical, innovative and dynamic attitude, so as to encourage students to have competence in the fields of science, technology, art and or sports.

g. Religious education is held interactively, inspiring, fun, challenging, encouraging creativity and independence, as well as growing motivation to live a successful life.

h. Education units can add content for religious education as needed. ${ }^{25}$

Based on the government regulations above, it is clear that there is a guarantee of freedom to develop Islamic religious education in schools, senior high school, starting from the implementation of education, the content of religious education materials, the direction and purpose of organizing religious education, teaching religious education and religious education wine. must be adjusted to the level of development of the students,

The model of the implementation of religious education must pay attention to the psychological and pedagogical potential that exists in students according to the level of development, the model of Islamic education must be oriented to the philosophy of life, namely:

a. Philosophy, that views students as servants of God who are given the ability to fitrah, dynamic, social, religious and perfect physical.

b. Etymologically, that students have the potential for knowledge to uphold a faith that has monotheism, basyariyah dharuriah, becomes a real Muslim human being and has a high degree.

c. Pedagogical, that students are learning creatures from birth to death whose development process is based on Islamic values, which are dialogical to the demands promised by Allah and the demands of community change, more inclined to a harmonious lifestyle between the interests of the world and the hereafter and his learning ability is motivated by human interests as caliphs on this earth. ${ }^{26}$

This religious education model can be formatted as follows:

\footnotetext{
${ }^{25}$ Republic of Indonesia Constitution No. 20 year 2003 about the national education system chapter IV, 231-232

$\underline{\text { html, }} 12$

26 http://kamiluszaman.blogspot.com/2015/09/model-pendidikan-islam-dan-orientasinya.
} 
a. The content of the material is more concentrated on socio-cultural problems today towards projections into the future, by looking at the development of students' abilities based on educational goals and values in accordance with Islamic teachings. So that daily life can carry out religious teachings both personally, as a family, in society, as a nation and as a state.

b. Educators must be responsible for creating the right religious education situation for students and according to their needs, by providing motivation, direction, communication that creates creative and innovative power in students which of course leads to the success of Islamic religious education which is expected to be in accordance with its objectives.

c. Students in the learning process must of course have communicative relationships between friends and educators so as to create a harmonious, dialogical, interactive, inspiring and even fun relationship that can provide encouragement in the success of Islamic religious education. In addition, in the development of this educational model, students can behave and behave honestly, trustworthy, disciplined, hard working, independent, confident, competitive, cooperative, sincere and responsible.

So, the format of developing this religious education model is innovative, dialogical, inspiring, harmonious and even fun, not learning to preserve what is, conservative and passive and dogmatic so that it is able to absorb the teachings of Islam which are actually in accordance with the basic concepts contained in the al Qur'an. an and al hadith.

\section{Conclusion}

With the description of the paper that the author describes about the models of Islamic Education in Senior High School, the following conclusions can be drawn: 1. Islamic Education is a part of religious education that deals with aspects of attitudes and values, namely morals and religion which are shared responsibilities between family, community and government.To achieve the goals of Islamic education, elements of education are needed.

2. Islamic Education teaching materials in high school contain a) faith, b) worship, c) the Qur'an, d) morals, e) sharia, f) muamalah, and g) dates, which have implications 
for graduates who are able to develop and realize elements in the three domains of education, namely the cognitive, affective and psychomotor domains.

3. Implementation of Islamic education in high school can be done with approaches including a) experience, b) habituation, c) emotional, d) rational and e) functional.

4. Models of Islamic education in senior high schools include a) Islamic boarding system education, b) Integrated Islamic education, c) Islamic boarding school education, d) Kuttab education, e) various basic life skills education. In the development of this model of Islamic education, it must be oriented to the philosophy of life in the form of philosophical, etymological and pedagogical.

\section{BIBLIOGRAPHY}

Agama, Departemen RI, Petunjuk Pelaksanaan Kurilulum/GBPP Pendidikan Agama Islam Sekolah Menengah Umum, Jakarta : Dirjen Pembinaan Kelembagaan Agama Islam, 1994.

Ali, Mudzakkir, Membangun Model Pendidikan Kehidupan Beragama Berbasis Life Skills di Pesantren, , Journal Edukasi, Vol. 10, Nomor 3 SeptemberDesember 2012. 
Darwis, Djamaluddin , Dinamika Pendidikan Islam Sejarah, Ragam dan Kelembagaan, Semarang : Rasail, 2010.

Daradjat, Zakiah, et al., Ilmu Pendidikan Islam, Jakarta : Bumi Aksara, 2011.

Depdikbud RI, Kurikulum SMU-GBPP PAI, Jakarta : Depdikbud RI, 1995.

Fajri, M Zul , Kamus Lemngkap Bahasa Indonesia, Jakarta : Difa Publisher, 2008.

Hadjar, Ibnu, Pendekatan Keberagamaan dalam Pemilihan Metode Pengajaran Pendidikan Agama Islam, Yogyakarta : Pustaka Pelajar, 1999.

http://kamiluszaman.blogspot.com/2015/09/model-pendidikan-islam-danorientasinya. html,

https://teropong.id/forum/2019/12/18/arti-kata-model-dalam-kamus-besar-bahasaindonesia-kbbi-adalah/

Miarso, Yusufhadi , Penerapan Teknologi Informasi dan Komunikasi dalam Pendidikan di Era Globalisasi. Jakarta: Makalah Seminar Nasional The Power of ICT in Education, PPs UNJ, 15 April 2008.

Nata, Abudin , Kapita Selekta Pendidikan Islam : Isu-isu Kontemporer tentang Pendidikan Islam, Jakarta : Raja Grafindo Persada, 2013.

Nata, Abudin, Kapita Selekta Pendidikan Islam, Bandung : Angkasa, 2003.

Robbins, Stephen P. , Organizational Behavior: Concepts, Controversies, Applications, Prentice-Hall International, Inc, 1996.

Thoha, M. Chabib and Mu'ti, Abdul, PBM PAI di Sekolah (Eksistensi dan Proses Belajar Mengajar Pendidikan Agama Islam, Yogjakarta : Pustaka Pelajar, 1998.

Thoha, M. Chabib, et al., Reformulasi Filsafat Pendidikan Islam, Yogjakarta : Pustaka Pelajar, 1996.

RI Law No. 20 of 2003 concerning National Education System Chapter IV in the Collection of Laws and Government Regulations of the Republic of Indonesia concerning Education, Jakarta: Director General of Islamic Education, Ministry of Religion, Republic of Indonesia, 2007. 